I Nengah Susrama. Pengaturan...

\title{
PENGATURAN HUKUM BAGI PELAKU PEDAGANGAN MANUSIA MELALUI MEDIA INTERNET DI INDONESIA
}

\author{
Oleh \\ I Nengah Susrama \\ Fakultas Hukum Universitas Mahasaraswati Denpasar
}

\begin{abstract}
Absract
In Indonesia, cases of perpetrators of human trafficking are still common. Today, with advances in technology and information, we often encounter cases of traffickers on the internet. In this journal, the author will discuss criminal sanctions regarding traffickers and about the role of Law Number 19 Year 2016 concerning Amendments to Law Number 11 Year 2008 concerning Information and Electronic Transactions in handling cases of trafficking perpetrators on the internet. This research method uses a normative juridical approach which looks at the problem from the study of legal materials such as books or articles that discuss human trafficking as a reference for staples and secondary legal materials. Human trafficking is categorized as a criminal act, which is more specifically a specific criminal act. In Indonesian criminal law has been regulated by various provisions. Provisions include prohibitions and eradication as stated in the Criminal Code, Legislation and in the Criminal Code Bill, Chapter XX, Articles 546-561 concerning human trafficking, where the application of sanctions is threatened with imprisonment and fines. Human trafficking is an organized and systematic crime, in which people included in it have personal or group interests to gain profit.
\end{abstract}

Keywords: Human Trafficking, Legal Regulations, Internet.

\begin{abstract}
Abstrak
Di Indonesia, Kasus pelaku tindak pidana perdagangan manusia masih banyak ditemui. Dewasa ini, dengan kemajuan teknologi dan informasi, seringkali kita temui kasus-kasus pelaku perdagangan manusia di internet. Dalam jurnal ini, penulis akan membahas mengenai sanksi pidana mengenai pelaku perdagangan manusia dan mengenai peran Undang-Undang Nomor 19 Tahun 2016 tentang Perubahan Atas Undang-Undang Nomor 11 Tahun 2008 tentang Informasi dan Transaksi Elektronik dalam penanganan kasus pelaku perdagangan manusia di internet. Metode Penelitian ini menggunakan pendekatan yuridis normatif dimana melihat permasalahan dari kajian bahan-bahan hukum seperti buku atau artikel yang membahas tentang perdagangan manusia sebagai referensi bahan pokok dan bahan hukum sekunder. Perdagangan manusia dikategorikan sebagai tindak pidana, yang lebih tepatnya tindak pidana khusus. Dalam hukum pidana Indonesia telah diatur dengan berbagai ketentuan. Ketentuan mencakup larangan dan pemberantasan seperti disebutkan didalam KUHP, Peraturan Perundang-Undangan dan didalam RUU KUHP, Bab XX, Pasal 546-561 tentang perdagangan manusia, yang penerapan sanksinya diancam dengan hukum pidana pidana penjara dan hukum pidana denda. Perdagangan manusia merupakan kejahatan yang terorganisir dan tersistematis, dimana orang yang termasuk didalamnya memiliki kepentingan pribadi atau kelompok untuk mendapat keuntungan.
\end{abstract}

Kata Kunci : Pelaku Perdagangan Manusia, Sanksi Pidana, Internet 


\section{A. PENDAHULUAN}

\section{Latar Belakang Masalah}

Dalam Pasal 1 Undang-Undang Republik Indonesia Nomor 21 Tahun 2007 tentang pemberantasan tindak pidana perdagangan orang, dirumuskan bahwa perdagangan orang (human trafficking) adalah tindakan perekrutan, pengangkutan, penampungan, pengiriman, pemindahan, atau penerimaan seseorang dengan ancaman kekerasan, penggunaan kekerasan, penculikan, penyekapan, pemalsuan, penipuan, penyalahgunaan kekuasaan atau posisi rentan, penjeratan utang atau memberi bayaran atau manfaat, sehingga memperoleh persetujuan dari orang yang memegang kendali atas orang lain tersebut, baik yang dilakukan di dalam negara maupun antar negara, untuk tujuan eksploitasi atau mengakibatkan orang tereksploitasi. Eksploitasi terhadap orang ini memiliki bentuk yang beragam. Di Indonesia, dikenal beberapa pekerjaan yang beresiko menjadi kasus human trafficking, diantaranya buruh migran, pembantu rumah tangga, pekerja seks komersial, pengantin pesanan dankawin kontrak, termasuk beberapa bentuk perburuhan pada anak. ${ }^{1}$

Human trafficking merupakan bentuk kejahatan yang paling tidak disadari oleh korban. Modusnya seringkali bersembunyi di balik kondisi kesulitan ekonomi dan finansial dengan menawarkan pekerjaan yang dibutuhkan dan membuat korban tidak berkesempatan bersikap kritis terhadap pekerjaan yang ditawarkan karena terdesak untuk hanya berpikir tentang bagaimana melanjutkan hidup. Keadaan Indonesia yang belum baik secara ekonomi membuat masyarakat memiliki orientasi yang tinggi pada kehidupan finansial. Situasi ini mendorong masyarakat terutama kalangan bawah untuk melakukan berbagai cara agar dapat memenuhi kebutuhan-kebutuhan hidupnya. Mereka amat beresiko terperosok dalam kondisi sosial berupa perdagangan manusia. Dorongan untuk hidup layak dengan cara apapun melemahkan mereka secara psikis. Apalagi jika dialami oleh para remaja dan anak-anak, bayangan tentang kehidupan yang mapan membuat mereka kurang mampu menyadari

${ }^{1}$ Rosenberg, R. Perdagangan perempuan dan anak di Indonesia. Jakarta. 2003. American Center for International Labor Solidarity (ACILS) 
bahaya di balik kasus human trafficking tersebut.

Menurut apa yang disampaikan oleh Yakushko², beberapa di antara banyak faktor yang menyebabkan kasus perdagangan manusia ini terjadi adalah kondisi kemiskinan, kurangnya pengetahuan dan informasi tentang ancaman perdagangan manusia, terjadinya konflik dan perang dalam suatu wilayah, serta praktek eksploitasi dan penyelundupan manusia. Apabila dipandang dalam perspektif proses faktor-faktor tersebut dapat menjadi dasar dalam merumuskan adanya individu, keluarga, atau komunitas yang rentan (vurnerable) terhadap ancaman perdagangan manusia.

\section{Menteri}

Pemberdayaan

Perempuan dan Perlindungan Anak Republik Indonesia menyatakan bahwa praktik penjualan anak, prostitusi anak dan pornografi anak mulai merambah melalui media sosial dengan memanfaatkan Facebook, Twitter dan media sosial lainnya. Kemajuan teknologi melalui penetrasi internet di media sosial tidak bisa dihindari. Keberadaan media sosial mempunyai

${ }^{2}$ Yakushko, O. Human Traficking : A review for mental health profesional. 2009. International Journal for the Advancement of Counseling, 31. Hal. 158-167 dampak positif dan negatif. Untuk itu, Menteri mengingatkan agar pemahaman terhadap penggunaan teknologi informasi yang semakin maju harus diimbangi dengan pemahaman moral serta pendidikan yang baik agar terhindar menjadi korban. Meskipun Kementerian Pemberdayaan Perempuan dan Perlindungan Anak belum memiliki data akurat tentang besaran perdagangan anak melalui media sosial namun dapat memprediksi bahwa angkanya lebih tinggi dibandingkan dengan perdagangan anak secara konvensional. Perdagangan anak secara konvensional dilakukan di daerahdaerah terpencil yang dari segi pendidikan dan ekonomi masih belum cukup baik. Namun demikian perkembangan media sosial yang mulai merambah desa-desa perlu diwaspadai .$^{3}$

Sementara itu, data menunjukkan bahwa 27 dari 129 anak yang dilaporkan hilang kepada Komisi Nasional Perlindungan Anak Indonesia diyakini telah diculik setelah bertemu penculiknya di Facebook. Salah satu

\footnotetext{
3 "Kejahatan internet terhadap anak dan orang dewasa yang sering terjadi”. Diakses darihttp://infoindonesiakita.com/2010/01/05/kej ahatan-internet-terhadap-anak-dan-orangdewasa-yang-sering-terjadi/, diakses tanggal 10 April 2020
} 
dari korban tersebut ditemukan tewas.

Dalam bulan yang sama setelah gadis dari Depok ditemukan di sebuah terminal bus pada 30 September 2015, setidaknya ada tujuh laporan penculikan gadis muda di Indonesia oleh orangorang yang mereka temui di Facebook. Penculikan 27 orang terkait Facebook yang dilaporkan oleh Komisi Anak tahun ini telah melebihi 18 kasus yang dilaporkan pada $2011 .{ }^{4}$

Mulai banyaknya kasus perdagangan manusia melalui penggunaan media sosial membuat masyarakat harus meningkatkan pemahaman tentang penggunaan teknologi informasi. Dalam hal ini yang paling memprihatinkan adalah kenyataan bahwa korban potensial yang mengakses media sosial kebanyakan adalah anak-anak dan remaja. Kita tahu bahwa cybercrimeatau kriminalitas yang di jalankan melalui aktivitas online sudah terjadi antar negara atau berjejaring internasional. Oleh sebab itu, penting bagi anak-anak dan remaja lebih terkendali dalam mengakses media sosial dan sebaiknya

\footnotetext{
4"Facebook digunakan untuk penculikan dan perdagangan anak perempuan". Diakses darihttp://www.voaindonesia.com/content/faceb ook-digunakan-untuk-penculikan-danperdagangananakperempuan/1535137.html. Diakses pada tanggal 10 April 2020
}

mendapatkan pengawasan dari orangtua dan sekolah.

Berdasarkan pembahasan diatas maka disini penulis akan mengangkat dua permasalahan yang akan dibahas dalam jurnal ini, adapun kedua permasalahan tersebut adalah sebagai berikut :

1. Bagaimana penerapan sanksi pidana terhadap kasus pelaku perdagangan orang di Indonesia ?

2. Bagaiamana peran UndangUndang Nomor 19 Tahun 2016 tentang Perubahan Atas Undang-Undang Nomor 11 Tahun 2008 tentang Informasi dan Transaksi Elektronik dalam penanganan kasus pelaku perdagangan orang di Internet?

Metode penelitian ini menggunakan metode penelitian yuridis normatif dimana melihat permasalahan dari kajian bahan-bahan sebagai referensi yang digunakan adalah peraturan perundang-undangan sebagai bahan pokok (bahan hukum primair) dan bahan hukum sekunder adalah seperti literatur-literatur, buku-buku hukum, karya ilmiah, artikel-artikel ilmiah yang membahas tentang pengaturan dan penerapan sanksi pidana 
terhadap pelaku perdagangan orang (human trafficking).

\section{B. PEMBAHASAN}

\section{Penerapan Sanksi Pidana} terhadap pelaku tindak pidana perdagangan orang di Indonesia

Perdagangan orang merupakan bentuk perlakuan yang buruk dari pelanggaran harkat dan martabat manusia. Perdagangan orang ini telah meluas dalam bentuk jaringan kejahatan yang terorganisasi baik bersifat antar negara maupun luar negeri. ${ }^{5}$ Kejahatan yang terorganisir ini juga membuat pemerintah kerepotan dalam penanggulangannya maunpun dalam memberikan perlindungan kepada korban. ${ }^{6}$ Ketentuan mengenai larangan perdagangan orang pada dasarnya telah diatur didalam Kitab Undang-Undang Hukum Pidana (KUHP).

Pasal 297 KUHP:

"Barang siapa dengan sengaja menyebabkan atau memudahkan perdagangan anak laki-laki yang belum dewasa, diancam dengan

${ }^{5}$ Suhardin, Y. Tinjauan Yuridis Mengenai Perdagangan Orang Dari Perspektif Hak Asasi Manusia. Mimbar Hukum, Vol. 20. Oktober 2008. Hal. 442-558

${ }^{6}$ Alfian, A. Upaya Perlindungan Hukum Terhadap Korban Tindak Pidana Perdagangan Orang. Fiat Justisia Jurnal Ilmu Hukum, Vol.9. No. 3 Juli-September. 2015. Hal. 331-339 pidana penjara paling lama enam tahun".

Pasal 298 KUHP berbunyi :

Ayat 1 : Dalam hal pemidanaan berdasarkan salah satu kejahatan dalam pasal 281, 284, 290 dan 297 pencabutan hak-hak berdasarkan Pasal 35 No 1-5 dapat dinyatakan.

Ayat 2 : Jika yang bersalah melakukan salah satu kejahatan berdasarkan pasal 261, 297 dalam melakukan pencahariannya, maka hak untuk melakukan pencaharian itu dapat dicabut.

Pada perkembangan pengaturan undang- undang perdagangan orang di Indonesia UU No. 21 Tahun 2007 tentang pemberantasan tindak pidana perdagangan orang disahkan, digunakan KUHP Pasal 297 yang berbunyi "perdagangan perempuan dan anak lakilaki yang belum dewasa, diancam dengan pidana penjara paling lama 6 tahun, dan hanyalah pasal ini yang secara khusus menyebutkan perdagangan orang, walaupun demikian hal ini masih sangatlah tidak lengkap dan belum mengakomodasi perlindungan hukum terhadap perdaganan orang. 
Pada dasarnya kepada seorang pelaku suatu tindak pidana harus dikenakan suatu akibat hukum. Akibat hukum itu pada umumnya berupa hukuman pidana atau sanksi. Berdasarkan Pasal 10 KUHP jenis hukuman pidana dibagi menjadi dua, yaitu:

a. Pidana pokok yang terdiri dari pidana mati, pidanapenjara, pidana kurungan, pidana denda, pidanatutupan;

b. Pidana tambahan terdiri dari pencabutan hak-haktertentu, perampasan barang-barang tertentu, dan pengumuman putusan hakim.

Penerapan sanksi pidana di Indonesia yangimplementasinya pada dalam Kitab Undang-Undang Hukum Pidana (KUHP), penjatuhan sanksi pidana terhadap tindak pidana perdagangan orang (human trafficking) dalam KUHP diatur didalam buku II Pasal 295 ayat (1) angka 1 dan 2, Pasal 295 ayat (2), Pasal 296, Pasal 297, Pasal 298 ayat (1),(2) dan Pasal 506. Dari pengertian yang terdapat di dalam KUHP dapat dijabarkan sebagai berikut: ${ }^{7}$

${ }^{7}$ Maharano, I. Gst Ayu Stefani Ratna \& Atmadja, Ida Bagus Putra. Sanksi Pidana Terhadap Tindak Pidana Perdagangan Orang (Human Trafficking) di Indonesia. Kertha a) Dengan sengaja menyebabkan atau memudahkan perbuatan cabul yang korbannyaanak (kandung, tiri,angkat) dan anakanak dibawah pengawasannya; perbuatan pelaku sebagai mata pencaharian;

b) Perbuatan yang sama, tapi untuk orang dewasa;

c) Memperniagakan perempuan dan anak laki-laki;

d) Ada hukuman tambahan (1) pencabutan hak(asuh untuk prlaku yang korbannya anak), (2) pemecatan dari pekerjaan kalau kejahatan dilakukan dalam pekerjaannya

Undang-Undang nomor 21 tahun 2007 tentang pemberantasan tindak pidana perdagangan orang ini memberikan sanksi pidana yang cukup berat terhadap pelaku tindak pidana perdagangan manusia sebagai wujud perlindungan terhadap korban perdagangan manusia. Ketentuan pidana terdapat dalam pasal 2 hingga pasal 23 Undang- Undang nomor 21 tahun 2007 tentang pemberantasan tindak pidana perdagangan orang. Salah satu contoh Pasal 2 yang mengatur tentang dapat

Wicara, Vol. 04, No. 03 September 2015. Hal. 1-5 
I Nengah Susrama. Pengaturan...

151

dipidananya perbuatan seorang pelaku perdagangan manusia baik secara melawan hukum maupun memperoleh persetujuan dari orang yang memegang kendali atas orang lain yang bertujuan untuk mengeksploitasi. Pasal 2 UndangUndang nomor 21 tahun 2007 tentang pemberantasan tindak pidana perdagangan tersebut berbunyi : "Setiap orang yang melakukan perekrutan, pengangkutan, penampungan, pengiriman, pemindahan, atau penerimaan seseorang dengan ancaman kekerasan,penggunaan kekerasan, penculikan, penyekapan, pemalsuan, penipuan, penyalahgunaan kekuasaan atau posisi rentan,penjeratan utang atau memberi bayaran atau manfaat walaupun memperoleh persetujuan dari orang yang memegang kendali atas orang lain, untuk tujuan mengeksploitasi orang tersebut di wilayah negara Republik Indonesia, dipidana dengan pidana penjara paling singkat 3 (tiga) tahun dan paling lama 15 (lima belas) tahun dan pidana denda paling sedikit Rp120.000.000,00 (seratus dua puluh juta rupiah) dan paling banyak Rp. 600.000.000,00 (enam ratus juta rupiah).

Dalam rumusan Pasal 1 angka 4 UU No 21 Tahun 2007, pelaku adalah setiap orang perseorangan atau korporasi yang melakukan tindak pidana perdagangan manusia. Dalam pasal 2 sampai dengan 18, undangundang ini secara tegas merumuskan sanksi terhadap pelaku perdagangan orang. Berdasarkan pasal-pasal tersebut, dapat dikategorikan beberapa pelaku Tindak Pidana Perdagangan Orang , yaitu: Pertama, Agen perekrutan Tenaga Kerja (legal atau illegal) yang membayar agen/ calo untuk mencari buruh di desa- desa, mengelola penampungan, mengurus identitas serta KTP dan dokumen perjalanan, memberikan pelatihan dan pemeriksaan medis serta menempatkan buruh dalam kerjaannya di Negara tujuan. Meskipun tidaksemua, namun sebagian PJTK terdaftar melakukan tindakan demikian. Kedua, Agen/calo (mungkin orang asing) yang datang ke suatu desa, tetangga, teman, bahkan kepala desa, tokoh masyarakat, tokoh adat, maupun tokoh agama. Agen dapat bekerja secara bersamaan untuk PJTK terdaftar/tidak terdaftar, guna memperoleh bayaranuntuk tiap buruh yang direkrutnya. Ketiga, Majikan yang memaksa buruh bekerja dalam kondisi eksploitatif, tidak membayar gaji, menyekap buruh di tempat kerja, 
melakukan kekerasan seksual atau fisik terhadap buruh. Keempat, Pemerintah, yang terlibat dalam pemalsuan dokumen, mengabaikan pelanggaran dalam perekrutan tenaga kerja atau memfasilitasi penyeberangan perbatasan secara illegal (termasuk pembiaran oleh polisi/petugas imigrasi). Kelima, Pemilik/pengelola rumah bordil yang memaksa perempuan untuk bekerjadi luar kemauan dan kemampuannya, tidak membayar gaji atau merekrut dan mempekerjakan anak yang belum berusia 18 tahun.

\section{Peran Undang-Undang Nomor 19 Tahun 2016 tentang Perubahan Atas Undang- Undang Nomor 11 Tahun 2008 tentang Informasi dan Transaksi Elektronik dalam penanganan kasus pelaku perdagangan manusia di Internet}

Mendel and $\begin{array}{r}\text { Sharapov }^{8} \\ \text { menyatakan bahwa }\end{array}$
penggunaan
memfingan internet dan online untuk
telah teridentifikasi dan memunculkan
keprihatinan.

${ }^{8}$ Mendel, J \& Sharapov, K. Human Trafficking and online networks : Policy briefing. Budapest : Centre for Policy Studies, Central European University. 2014 aksesibilitas dan berkembangnya teknologi internet dan jaringan digital memungkinkan para pedagang manusia beroperasi dengan peningkatan efisiensi. Sementara itu, anonimitas jejaring sosial, iklan baris online dan situs kencan dapat digunakan untuk merekrut orang ke dalam perdagangan dan mengiklankan pekerjaan mereka. Jaringan anonim digunakan untuk mentransfer dan menukar data yang berlokasi di wilayah dengan yurisdiksi atau penegakan undang-undang cybercrime yang kurang ketat. Ada juga trend baru dimana penjahat mengandalkan peralatan portable seperti smartphone yang jika terpaksa mudah dibuang.

Dalam sebuah laporannya, peneliti di Pusat Komunikasi Kepemimpinan \& Kebijakan USC Annenberg mengungkapkan bagaimana mereka terlibat dalam kasus perdagangan manusia yang telah cepat beradaptasi dengan perkembangan global. Teknologi digital seperti ponsel, situs jejaring sosial, dan Internet memang telah memberikan manfaat yang signifikan bagi masyarakat dengan memunculkan saluran baru dan kesempatan untuk eksploitasi yang semakin tinggi. Eksesnya, bisnis 
perdagangan manusia sudah berlangsung secara online dan melalui ponsel. Di sisi lain teknologi yang sama saat ini juga dipergunakan untuk memerangi kasus human trafficking. Bagaimana teknologi digital berperan dalam perdagangan manusia belumlah terlalu jelas, namun beberapa penelitian yang dilakukan terhadap fenomena ini telah mengidentifikasi adanya peluang dan ancaman baru. Hasil investigasi mengungkapkan bahwa jaringan online telah digunakan untuk perdagangan seks anak di bawah umur di Amerika Serikat. Sementara saluran online seperti iklan baris online dan situs jejaring sosial tetap menjadi tempat potensial untuk eksploitasi.

Kemampuan ponsel untuk memfasilitasi komunikasi dan koordinasi yang tidak terikat oleh lokasi fisik juga dimanfaatkan oleh pedagang untuk memperluas jangkauan kegiatan terlarang mereka. Merekrut, mengiklankan, mengatur, dan berkomunikasi melalui perangkat telepon selular, efektif merampingkan kegiatan dan memperluas jaringan kejahatan mereka. Intinya, perdagangan manusia dan jaringan kejahatan yang mengambil keuntungan dari teknologi mendapat perhatian lebih besar karena secara teknis menggunakan teknologi informasi. ${ }^{9}$

Tidak ada aturan khusus mengenai TPPO dalam Undang-Undang Nomor 11 Tahun 2008 tentang Informasi dan Transaksi Elektronik ("UU ITE") sebagaimana yang telah diubah oleh Undang-Undang Nomor 19 Tahun 2016 tentang Perubahan Atas Undang-Undang Nomor 11 Tahun 2008 tentang Informasi dan Transaksi Elektronik.

Menurut hemat saya UU ITE dan perubahannya dapat digunakan untuk membantu proses pidana TPPO, dimana pengaturan jerat hukumnya sampai dengan pembuktiannya tetap mengacu kepada UU 21/2007. Hal ini sebagaimana diatur dalam Pasal 29 UU TPPO yang menyebutkan alat bukti selain sebagaimana ditentukan dalam Undang-Undang Hukum Acara Pidana, dapat pula berupa:

a. informasi yang diucapkan, dikirimkan, diterima, atau disimpan secara elektronik dengan alat optik atau yang serupa dengan itu; dan

${ }^{9}$ Latonero, M. Human Trafficking online : The role of social networking sites and online classfields. Research series : September 2011. Annenberg school for Communication and journalism, Center on Communication Leadership \& Policy. USC University of southern california 
b. data, rekaman, atau informasi yang dapat dilihat, dibaca, dan/atau didengar, yang dapat dikeluarkan dengan atau tanpa bantuan suatu sarana, baik yang tertuang di atas kertas, benda fisik apa pun selain kertas, atau yang terekam secara elektronik, termasuk tidak terbatas pada:

1. tulisan, suara, atau gambar;

2. peta, rancangan, foto, atau sejenisnya; atau

3. huruf, tanda, angka, simbol, atau perforasi yang memiliki makna atau dapat dipahami oleh orang yang mampu membaca atau memahaminya. ${ }^{10}$

Pasal 5 ayat (1) jo. (2) UU ITE menyatakan bahwa bukti elektronik sah menurut hukum, pasal tersebut bebunyi:

1. Informasi Elektronik dan/atau Dokumen Elektronik dan/atau hasil cetakannya rnerupakan alat bukti hukum yang sah. ${ }^{11}$

${ }^{10}$ Undang-Undang Nomor 19 Tahun 2016 tentang Perubahan Atas Undang-Undang Nomor 11 Tahun 2008 tentang Informasi dan Trnasaksi Elektronik

${ }^{11}$ Anotasi Putusan Mahkamah Konstitusi Nomor 20/PUU-XIV/2016: Frasa "Informasi Elektronik dan/atau Dokumen Elektronik" dalam Pasal 5 ayat (1) dan ayat (2) serta Pasal
2. Informasi Elektronik dan/atau

Dokumen Elektronik dan/atau hasil cetaknya sebagaimana dimaksud pada ayat (1) merupakan perluasan dari alat bukti yang sah sesuai dengan Hukum Acara yang berlaku di Indonesia.

Pada praktiknya, penegak hukum juga menjadikan handphone, bukti cetak pesan, informasi atau dokomen elektronik yang berhubungan dengan TPPO sebagai alat bukti.Namun terkait penyebaran informasi TPPO tentang (eksploitasi seksual-prostitusi online), perbuatan tersebut dapat dijerat dengan Pasal 45 ayat (1) UU 19/2016 jo. 27 ayat (1) UU ITE.

Pasal 27 ayat (1) UU ITE

"Setiap Orang dengan sengaja dan tanpa hak mendistribusikan dan/atau mentransmisikan dan/atau membuat dapat diaksesnya Informasi Elektronik

44 huruf $\mathrm{b}$ bertentangan dengan UUD 1945 dan tidak mempunyai kekuatan hukum mengikat sepanjang tidak dimaknai khususnya frasa "Informasi Elektronik dan/atau Dokumen Elektronik" sebagai alat bukti dilakukan dalam rangka penegakan hukum atas permintaan kepolisian, kejaksaan, dan/atau institusi penegak hukum lainnya yang ditetapkan berdasarkan undang - undang sebagaimana ditentukan dalam Pasal 31 ayat (3) UU No. 11 Tahun 2008 tentang Informasi dan Transaksi Elektronik. 
dan/atau Dokumen Elektronik yang memiliki muatan yang melanggar kesusilaan.”

Ancaman pidana terhadap pelanggar diatur dalam Pasal 45 ayat (1) UU 19/2016, yaitu:

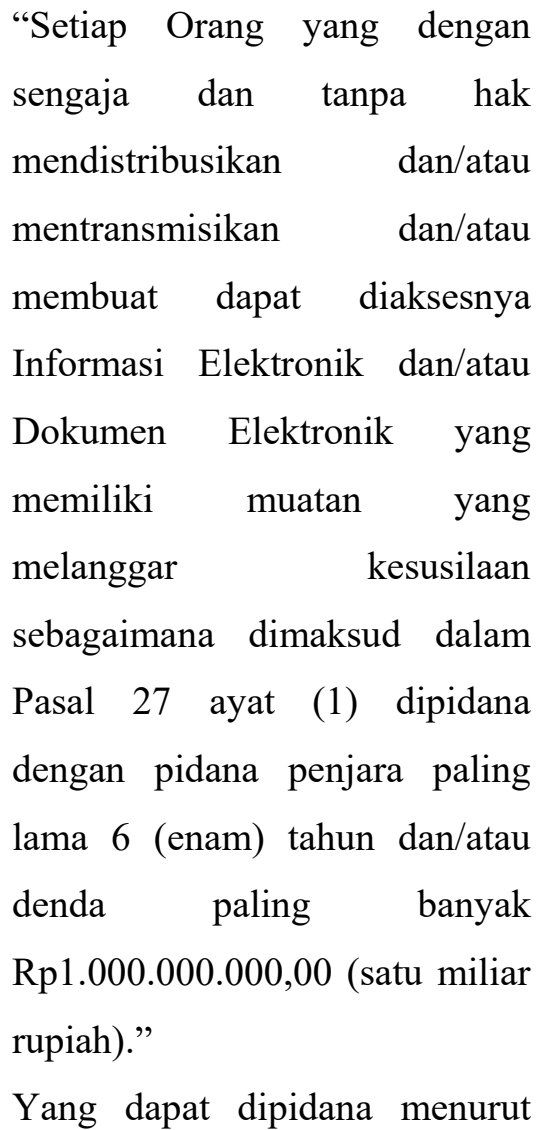

Pasal 45 ayat (1) UU 19/2016 jo. 27 ayat (1) UU ITE adalah perbuatan menyebarkan informasi elektronik TPPO yang bermuatan seksual (melanggar kesusilaan). Namun meskipun demikian terhadap perbuatan perdagangan orangnya, tetap menggunakan UU 21/2007 yang mengatur khusus mengenai TPPO.
Sebagai informasi, perlu diketahui bahwa tindakan prostitusi online berbeda dengan TPPO, sebagaimana disampaikan dalam artikel Awas Salah Memahami Prostitusi Sebagai TPPO menurut Profesor Harkristuti Harkrisnowo, Guru Besar Fakultas Hukum Universitas Indonesia, Prostitusi itu bukan perdagangan orang, tetapi perdagangan layanan seksual, karena ada perbedaan antara dia mau atau tidak. Ada perbedaan kehendak orang yang terlibat prostitusi dengan orang yang terlibat TPPO. Keduanya juga dapat dibedakan dari siapa pelaku atau orang di belakang tindak pidana itu. Dalam TPPO pelakunya adalah human trafficker, sedangkan di dalam prostitusi, yang di belakang pelaku adalah broker atau perantara.

\section{PENUTUP \\ 1. Kesimpulan}

Dari uraian diatas dapat diambil kesimpulan, bahwa tindak pidana perdagangan orang merupakan kejahatan yang terorganisir secara sistematis, dimana orang-orang yang termasuk didalamnya memiliki kepentingan-kepentingan secara pribadi dan atau kelompok. Tindak pidana perdagangan orang ini juga dikategorikan sebagai kejahatan yang 
melanggar HAM seseorang, dimana para pelaku menjajakan orang-orang untuk menjadi pekerja- pekerja yang memberikan keuntungan bagi mereka.

Dalam hal terjadi TPPO, maka pelakunya tetap dijerat dengan UU 21/2007. Namun tidak tertutup kemungkinan, khusus dalam kondisi tertentu, seperti pendistribusian dan/atau pentransimisian informasi elektronik dan/atau dokumen elektronik yang memiliki muatan yang melanggar kesusilaan, dapat juga dijerat dengan UU ITE, misalnya menyebarkan gambar atau informasi tentang TPPO di media sosial. Sehingga tetap saja terhadap kasus TPPO yang digunakan secara khusus adalah UU 21/2007 yang mengatur khusus mengenai TPPO, bukan UU ITE.UU ITE dan perubahannya dapat digunakan untuk membantu proses pidana TPPO, dimana pengaturan jerat hukumnya sampai dengan pembuktiannya tetap mengacu kepada UU 21/2007.

\section{DAFTAR PUSTAKA}

\section{BUKU :}

Rosenberg, R Ed. 2003. Perdagangan perempuan dan anak di Indonesia. Jakarta: American Center for International Labor Solidarity (ACILS).

Mendel, J., \& Sharapov, K. 2014. Human trafficking and online networks: Policy briefing. Budapest: Centre for Policy Studies, Central European University.

\section{Jurnal :}

Suhardin, Y. (2008). Tinjauan Yuridis Mengenai Perdagangan Orang Dari Perspektif Hak Asasi Manusia. Mimbar Hukum, Vol.20, No.3, Oktober

Yakushko, O. (2009). Human traficking: A review for mental health profesional. International Journal for the Advancement of Counseling, 31.

Alfian, A. 2015. Upaya Perlindungan Hukum Terhadap Korban Tindak Pidana Perdagangan Orang. Fiat Justisia Jurnal Ilmu Hukum, Vol.9, No. 3, Juli-September.

Maharani, I. Gst. Ayu Stefani Ratna., \&Atmadja, Ida Bagus Putra. 2015. Sanksi Pidana Terhadap Tindak Pidana Perdagangan Orang (Human Trafficking) di Indonesia. Kertha Wicara, Vol. 04, No. 03, September. 
Latonero, M.2011. Human trafficking online: The role of social networking sites and online classifieds. Research Series: September 2011. Annenberg School for Communication and journalism, Center on Communication Leadership \& Policy. USC university of southern California

\section{Internet :}

"Kejahatan internet terhadap anak dan orang dewasa yang sering terjadi”. Diakses dari http://infoindonesiakita.com/2010/ 01/05/kejahatan-internetterhadap-anak-dan-orang-dewasayang-sering-terjadi/, diakses tanggal 10 April 2020

"Facebook digunakan untuk penculikan dan perdagangan anak perempuan" (2012). Diakses dari http://www.voaindonesia.com/con tent/facebook-digunakan-untuk penculikan-dan-perdagangananakperempuan/ 1535137.html, diakses tanggal 10 April 2020

\section{Peraturan Perundang-undangan :}

Undang-Undang Nomor 19 Tahun 2016 tentang Perubahan Atas UndangUndang Nomor 11 Tahun 2008 tentang Informasi dan Transaksi Elektronik
Anotasi Putusan Mahkamah Konstitusi Nomor 20/PUU-XIV/2016: Frasa "Informasi Elektronik dan/atau Dokumen Elektronik" dalam Pasal 5 ayat (1) dan ayat (2) serta Pasal 44 huruf $b$ bertentangan dengan UUD 1945 dan tidak mempunyai kekuatan hukum mengikat sepanjang tidak dimaknai khususnya frasa "Informasi Elektronik dan/atau Dokumen Elektronik" sebagai alat bukti dilakukan dalam rangka penegakan hukum atas permintaan kepolisian, kejaksaan, dan/atau institusi penegak hukum lainnya yang ditetapkan berdasarkan undang - undang sebagaimana ditentukan dalam Pasal 31 ayat (3) UU No. 11 Tahun 2008 tentang Informasi dan Transaksi Elektronik. 